\title{
Microbial and viral contamination of animal and stem cell cultures: common contaminants, detection and elimination
}

\begin{abstract}
The microbial contamination of animal cell culture, including stem cells, such as the blood stem cells, is a common problem of cell culture laboratories. It is important to identify the types of microorganisms commonly contaminating the cell culture and the sources of contaminating microorganisms, as well as see their effects on cells in culture. This mini review provides a short account of common microbial contaminations of stem cell and animal cell cultures, their detection and elimination, as well as standard practices to ensure a healthy and sterile cell culture, and a brief account of methods used for identification of contaminating microorganisms in cell culture.
\end{abstract}

Keywords: bacteria, mycoplasma, protozoa, yeast, fungi, virus, animal and stem cell culture, contamination, culture practices
Volume 2 Issue 5 - 2017

\author{
Amena Mahmood,' Shakir Ali ${ }^{1,2}$ \\ 'Department of Biochemistry, School of Chemical and Life \\ Sciences, India \\ 2Bioinformatics Infrastructure Facility, Jamia Hamdard (Deemed \\ University), India
}

Correspondence: Shakir Ali, Regenerative Medicine Lab, Department of Biochemistry, School of Chemical and Life Sciences, Jamia Hamdard, New Delhi I 10062 , India, Tel +9 I I I26059688, Fax +9| I | 26059663,

Email sali@jamiajamdard.ac.in

Received: March 24, 2017 | Published: May 15, 2017

\section{Introduction}

Secondary or continuous cell lines are a significant resource, a viable alternative, and an effective tool in understanding the fundamental cell processes, common diseases, drug discovery, manufacturing biologicals, and in cell therapies. Culturing animal cells require a highly nutrient medium which attracts microorganisms and their spores, thereby exposing the cells to microbial contamination and compromising its growth and characteristics in culture medium. It may lead to a very common and basic problem of misidentification, spoil the research results, compromise the comparison of results in different laboratories, diminish the use of cell culture for medical purpose, such as stem cell therapy, and lead to unusable therapeutic products. ${ }^{1}$ Cell therapy and regenerative medicine, which are potentially two of the most exciting aspects of the novel therapeutic methods currently under development, present a significantly higher risk of possible transmission of microorganisms to the recipients, most commonly by bacteria, yeast and fungi. In an analysis of 32 stem cell lines and feeder cell lines, there were 19 contaminated cell passages $(12 \%)$ - the main contaminants were gram positive cocci and Mycoplasma species, followed by gram negative rods and gram positive rods. ${ }^{2}$ In this study, the Mycoplasma contamination rate was $4 \%$. The microbial contamination of hematopoietic stem cell products may lead to potentially fatal complication of hematopoietic stem cell transplantation. In a study on the incidence of contaminated products and their clinical outcomes at the University of Minnesota in patients who received contaminated products between January 1990 and December 2004, 1.2\% were contaminated. ${ }^{3}$ Coagulase-negative Staphylococcus was the predominant species isolated on culture of the hematopoietic stem cell products. In such contaminations, prophylactic antibiotics are found to be useful, but caution must be exercised when gram-negative contaminated products, such as Pseudomonas cepacia, found in sewage or water supplies, are administered. Even the storage can be a contributing factor in contamination. In a study by Honohan, ${ }^{4}$ low levels of contaminating bacteria in cord blood were reported to reach bacteraemic levels causing severe transfusion-associated sepsis after storage. Screening the processed cell lines for contamination by research centres and stem cell banks, and to assure that no contaminants are introduced in the banking procedures is the simplest way to reduce the probability of contamination in the final product.

\section{Microbial contamination of cell culture: incidences} and sources

All types of microorganisms including yeast, mould, protozoa (Giardia intestinalis, Entamoeba histolytica; protozoan contaminations are rare in cell culture), bacteria and viruses may contaminate cells in culture. The animal/stem cell culture media are rich in nutrients like glucose and ammonia, apart from salts and other trace elements and micronutrients. These constituents of the nutrient medium provide minimal requirement for the growth of microorganisms such as Mycoplasma, Escherichia coli, Saccharomyces cerevisiae and other microorganisms. ${ }^{5}$ Glucose in the medium is a source of carbon and its metabolism to smaller molecules (e.g., $\mathrm{CO}_{2}$, ethanol, or acetic acid) generates ATP necessary for energyrequiring activities of cells. Ammonium is the sole nitrogen source from which an animal cell can synthesize essential amino acids and other nitrogen-containing substances. ${ }^{6}$ The airborne microorganisms can easily enter and outgrow desired cells in culture, if the good culture practices are not followed. The presence of serum in animal cell culture medium particularly makes it prone to contamination by microbial species, which may spread via physical means, like sharing media and reagents, using unplugged pipettes, improper handling and use of non-sterile reagents, accidental spilling or contact etc. Lotto-lot variation in hormones and growth factors in sera, presence of endotoxins in water or sera or other culture additives (trypsin, amino acids etc), free radicals generated in media by the photo-activation of tryptophan, riboflavin or HEPES exposed to fluorescent light can all 
spoil a culture medium. ${ }^{7}$ Residues from germicides used to disinfect incubators, equipments and labs, and impurities in gases used in $\mathrm{CO}_{2}$ incubators have also been found to affect cell culture. ${ }^{8}$ However, the major source of microbial contamination is documented to arise by contact with non-sterile supplies, media and solution, chemicals and equipments, and by the particulate matter and aerosols that fall out during transportation and incubation. ${ }^{9}$ According to a study, 1960-70, the new born bovine serum obtained from commercial suppliers was found to be a major source of bacterial, particularly the mycoplasma, contamination. ${ }^{10}$

One of the most common contaminants, and also difficult to detect, that has been reported in literature is Mycoplasma contamination. ${ }^{11}$ Mycoplasma is an intracellular bacterium that may go unnoticed for many passages. Its presence can change several cell properties such as the growth, metabolism, morphology, and genome structure. In literature, the incidences of Mycoplasma contamination have been reported over a period of time since $1956 .{ }^{12}$ The incidence of Mycoplasma contamination was $19 \%$, as compared with fungal $(8 \%)$ and other bacterial (4\%) contaminations. The contamination is reported to spread through airborne particles and non-sterile surfaces mainly. ${ }^{13}$ In a study on fibroblasts and keratinocyte cell lines, $32.35 \%$ cultures were contaminated, and among these, the mycoplasma contaminated cultures were $17.65 \%$, followed by fungal $(8.82 \%)$ and bacterial $(5.88 \%)$ contaminants. ${ }^{14}$

Aspergillus tops the list of fungal contamination of cell cultures. ${ }^{15}$ $M$. orale is reported to be the most common contamination that can spread from human oral cavity, and hence making the lab workers a major source of this contamination. ${ }^{10}$ Bacterial species (Bacillus sp., Enterococcus sp. and Staphylococcus $\mathrm{sp}$ ) are similarly some major contaminants of animal cell cultures. ${ }^{9}$ A list of common microbial species and their major sources that have been reported to contaminate animal/stem cell culture is provided in Table $1 \& 2$, respectively.

Table I Common microbial and viral contaminations of animal and stem cell culture

\begin{tabular}{|c|c|}
\hline Microorganism/virus & Reference \\
\hline \multicolumn{2}{|l|}{ Mycoplasma } \\
\hline M. orale $(20-40 \%)$ & 16,43 \\
\hline M. hyorhinis & 40 \\
\hline M.fermentans & 10 \\
\hline M. hominis & 16,43 \\
\hline$M$ arginini & 43 \\
\hline \multicolumn{2}{|l|}{ Bacteria } \\
\hline Escherichia coli & 15 \\
\hline Bacillus cereus & Timm Seabra Souza F et al. 2004 \\
\hline Bacillus coagulans & 15 \\
\hline Bacillus brevis & 46,47 \\
\hline Enterococcus malodoratus & $43,46,47$ \\
\hline Enterococcus casseliflavus & 46,47 \\
\hline Staphylococcus epidermidis & 43 \\
\hline Staphylococcus felis & 43 \\
\hline \multicolumn{2}{|l|}{ Kluyveravulneris } \\
\hline \multicolumn{2}{|l|}{ Fungi } \\
\hline Candida sp. & 44 \\
\hline Penicilliumsp. & 44 \\
\hline Aspergillus niger & 15 \\
\hline Aspergillus flavus & 14,15 \\
\hline Botrytis sp. & 14 \\
\hline Paecilomyces sp. & 14,44 \\
\hline \multicolumn{2}{|l|}{ Virus } \\
\hline Hepatitis viruses : HBV, HCV, HDV, HEV, HGV & Simmonds 200I \\
\hline Human Retroviruses : HIV-I, HIV-2, HTLV-I, HTLV-2 & Hjelle et al. 1992 \\
\hline Papovaviruses & Butel 1996 \\
\hline
\end{tabular}


Table 2 Major sources of microbial contaminations and methods to eliminate the contaminating species

\begin{tabular}{|c|c|c|}
\hline $\begin{array}{l}\text { Source of } \\
\text { contaminant } \\
\text { (microbial, and also } \\
\text { chemical) }\end{array}$ & $\begin{array}{l}\text { Method of its removal/ } \\
\text { precautions }\end{array}$ & Reference \\
\hline $\begin{array}{l}\text { Reagent and water } \\
\text { used for preparing } \\
\text { media }\end{array}$ & $\begin{array}{l}\text { Micro filtration }(0.22 \mu) \text {, } \\
\text { autoclave }\end{array}$ & 45 \\
\hline $\begin{array}{l}\text { Endotoxins from sera, } \\
\text { water, media and some } \\
\text { culture additives }\end{array}$ & $\begin{array}{l}\text { Ultra filtration and ion } \\
\text { exchange, Litmus Amebocyte } \\
\text { Lysate Assay }\end{array}$ & 39 \\
\hline $\begin{array}{l}\text { Impurities in gases used } \\
\text { in } \mathrm{CO}_{2} \text { incubator }\end{array}$ & $\begin{array}{l}\text { Use of correct gas cylinders, } \\
0.22 \mu \text { filters between the } \\
\mathrm{CO}_{2} \text { incubator and cylinders }\end{array}$ & 8 \\
\hline $\begin{array}{l}\text { Free radicals generated } \\
\text { in media by the } \\
\text { photo-activation of } \\
\text { tryptophan, riboflavin, } \\
\text { HEPES exposed to } \\
\text { fluorescent light }\end{array}$ & $\begin{array}{l}\text { Do not leave feeding culture } \\
\text { on lab benches for long and } \\
\text { do not store media in cold } \\
\text { facilities with light }\end{array}$ & 47 \\
\hline $\begin{array}{l}\text { Deposits in glassware, } \\
\text { pipettes, instruments } \\
\text { etc left by disinfection } \\
\text { or detergent }\end{array}$ & $\begin{array}{l}\text { Washings with ether- } \\
\text { chloroform. }\end{array}$ & 7 \\
\hline Bacteria , yeasts, fungi & $\begin{array}{l}\text { Use antibiotics and } \\
\text { antimycotics, discard the } \\
\text { contaminated culture, clean } \\
\text { and disinfect all surfaces } \\
\text { followed by reviving a fresh } \\
\text { culture }\end{array}$ & 43 \\
\hline Virus and Mycoplasma & $\begin{array}{l}\text { Discard contaminated culture. } \\
\text { Test the stock for sterility } \\
\text { before reviving }\end{array}$ & 16 \\
\hline
\end{tabular}

\section{Viral contamination}

Incidences of viral contamination are also not uncommon in cell culture. Human cells may be infected by viruses like hepatitis viruses, retroviruses, herpes viruses or papillomaviruses. ${ }^{16}$ The mouse epithelial pancreatic cell lines have been reported to be contaminated by polyoma virus from the mouse with which these cells were isolated. ${ }^{16}$ Primary kidney cells isolated during the period from 1954-1961 from macaque or rhesus monkeys were found to be contaminated with SV40. ${ }^{17}$ The retroviruses have been reported to contaminate murine hybridomas during production. ${ }^{18} \mathrm{~A}$ common instance of viral contamination includes the adeno-associated virus (AAV), where the provirus is present but assistance of a helper virus is needed for replication. ${ }^{19,20}$ The experimental results of viral contamination suggest that HTLV-I or HTLV-II undergo phenotypic mixing with HIV-1 in HTLV/HIV-1 co-infected cells, leading to an increase of the pathogenicity of HIV-1 by broadening the spectrum of its cellular tropism to CD4 negative cells. ${ }^{21}$ Similarly LCMV is an arenavirus that establishes a silent, chronic infection in mice but causes aseptic meningitis, encephalitis or meningoencephalitis to humans. LCMV contamination produced cases of laboratoryacquired LCMV infections arising from contaminated murine tumour cell lines..$^{22}$ Viruses, being intracellular obligatory parasites, often go unnoticed in cell culture as contamination due to integration of viral genome is not visually detected; although viruses such as HIV, herpes viruses and adenoviruses, causing cytopathic effects are detectable by microscope. Viruses like lactate dehydrogenase virus (LDV) usually get diluted subsequently during passaging and cell line can become virus free. ${ }^{23}$

\section{Detection of microbial and viral contamina- tion and methods for their identification and elimination}

There are various methods for identification of cell lines, and possible culture contamination. These methods are instrumental in cell based therapies and in the manufacturing of recombinant protein therapeutics, as well as in basic cell science research. In culture medium, the bacterial contaminations cause a sudden drop in the $\mathrm{pH}$ of the culturing media, which becomes turbid. Like bacterial contamination, cultures contaminated with yeasts also become turbid, especially if the contamination is in an advanced stage (Figure 1). There is very little change in the $\mathrm{pH}$ of the culture contaminated by yeasts until the contamination becomes heavy, at which stage the $\mathrm{pH}$ usually increases. Under microscope, yeast appears as individual ovoid or spherical particles which may bud off smaller particles. ${ }^{24}$ Upon mould contamination, the $\mathrm{pH}$ of the culture remains stable in the initial stages of contamination and then it increases rapidly as the culture becomes more heavily infected and becomes turbid.

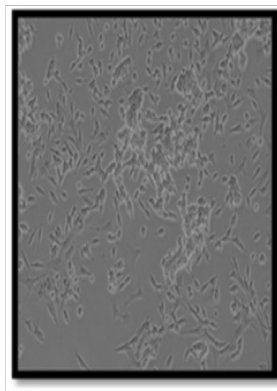

(A)

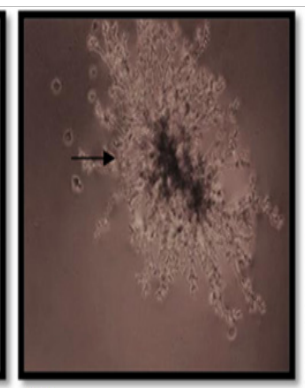

(B)

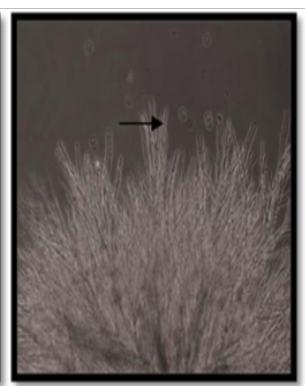

(C)
Figure I Fungal contamination in HepG2 cells. (A) Uninfected HepG2 cells, (B, C) Infected cells, with arrows indicating the mycelia growth. Magnification, IOX.

STR profiling is one of the common methods to identify cells in animal cell culture laboratories. In this method, the DNA is profiled through short tandem repeats (STRs). The American National Standard Institute (ANSI) provides information on how to use STR profiling for authenticating human cell lines. ${ }^{25}$ DNA isolation is done from the exponential phases of cell cultures followed by PCR amplification of STR obtained. Following amplification, gel electrophoresis is performed to detect amplified STR fragments. Further STR profile is generated by converting the size of amplicons obtained to the number of core sequence repeats using an allelic ladder. The generated STR profile is compared with an appropriate reference database for cell line authentication. ${ }^{26}$ Most of the results are stored in public access database of authenticated DNA profiles. Various labs can compare most of the human cell lines they use with this published data. The methods to identify non-human species cell lines are different than human cell lines and involve testing for species specificity, ${ }^{27}$ since unique STR markers for distinguishing non-human cell lines have not been available. A series of STR markers that distinguish African green monkey, Chinese hamster and mouse cell lines have been identified. ${ }^{28}$ Nine of those markers have been successfully used in multiplex PCR assay. ${ }^{29}$ 
The isoenzyme analysis, ${ }^{30}$ karyotyping $^{31}$ and DNA barcoding (mitochondrial DNA typing) ${ }^{32}$ are some other commonly used methods to identify and verify the species of origin. In isoenzyme analysis, the isoenzyme specimens can be differentiated based on electrophoretic properties. Distribution patterns of a group of enzymes are characteristic of a particular species which simultaneously confirms the species identity and reveals contamination by a different species. PCR-RFLP can be used as a less expensive and time-consuming alternative to iso-enzymatic analysis. It has been reported to identify the species of origin of 23 different animal cells, as well as to detect interspecies cross-contamination. ${ }^{33}$

The contamination by microorganisms like bacteria, fungi and yeast contamination is relatively easier to detect. The mycoplasma contamination, which is the most common, is perhaps the most difficult to detect until it achieves extremely high densities and causes the cell culture to deteriorate. ${ }^{34}$ Chronic mycoplasma infections might manifest themselves with decreased rate of cell proliferation, reduced saturation density and agglutination in suspension cultures. The only assured way of detecting mycoplasma contamination is by testing the cultures periodically using fluorescent staining (Figure 2), which include Hoechst 33258, ELISA, PCR, immunostaining, autoradiography, or microbiological assays. ${ }^{34}$
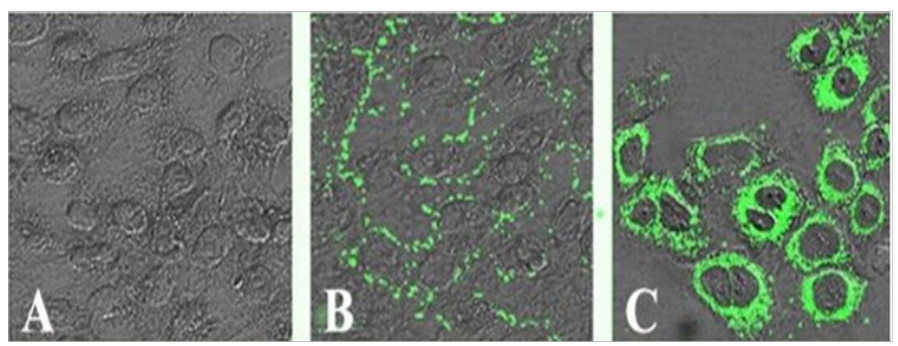

Figure 2 Confocal micrographs showing internalization of $M$. hyorhinis (green fluorescence) by melanoma cells. (A) Uninfected melanoma cells, (B) Formaldehyde fixed melanoma cells infected with Mycoplasma (bacteria on the melanoma cell surface), and C) Native melanoma cells infected by Mycoplasma. [Image reproduced with permission: Rottem et al. Contamination of Tissue Cultures by Mycoplasmas, Biomedical Tissue Culture; Ceccherini-Nelli, L., Ed.; ISBN: 978-953-5I-0788-0; InTech, DOI: I0.5772/5I5I8.]

There is a lack of effective measures to detect viral infections. ${ }^{16}$ Viral infection of cell cultures can be detected by electron microscopy, immune-staining, ELISA assays, or PCR with appropriate viral primers The RTase (reverse transcriptase) test detects presence of all viruses having reverse transcriptase.$^{35}$ These days, however, ultrasensitive RT tests, product-enhanced reverse transcriptase (PERT) assays, have been designed having detection limit that is $10^{6}-10^{7}$ times lower than that of conventional RT tests. ${ }^{36}$ Thin section and negative stain electron microscopy (EM) examination have been instrumental in identifying viruses in growing cultures, for example, the Filoviridae (ebolavirus), monkeypox virus, Bunyaviridae. EM provides the initial information about the etiologic agent, thereby initiating further investigations to characterize strain by serologic testing, immunohistochemical (IHC) and indirect fluorescence antibody (IFA) assays. Virus that belongs to family Arenaviridae was identified by EM first and then characterised as lymphocytic choriomeningitis virus (LCMV), an arenavirus transmitted by rodents using IFA assay and PCR. ${ }^{37}$ The West Nile virus (WNV) is a member of the family Flaviviridae. Genus Flavivirus was identified by immunohistochemistry in the US. Viral contamination can be screened and compared against normal tissues for IHC. However, extra care should be taken to prevent exposure of lab personnel to live virus during and beyond the initial sample collection. ${ }^{38}$ Besides the techniques for detection of microorganisms, it is important to adopt standard practices to avoid microbial contamination (Table 3). For example, upon obtaining a cell line from another source, the original source must be mentioned and retained. Any genetic modification, sub-line and clone should be indicated by a suffix, following the origin. Cell lines obtained from cell bank must have its accession number retained. The source of cell lines must be uniquely mentioned to avoid any ambiguity with other cell lines and for accessible literature searches. The morphology check is the simplest and a direct method to identify a particular type of cell by inverted microscope and comparing it with available data.

\section{The effect of microbial contamination on cell lines}

Cell lines are generally contaminated due to uninformed introduction of a microorganism. The presence of microorganism in culture medium may affect growth of culture, thereby compromising the quality of results and their reproduction. Mycoplasma contamination is a biosafety issue, because some of the contaminating Mycoplasma species belong to risk group. Mycoplasma for the first time was isolated from a contaminated cell culture in 1956 and since then $15-35 \%$ continuous cell lines have been reported mycoplasma contaminated..$^{39}$ M. pneumoniae and $M$. hominis account for more than $96 \%$ of mycoplasma contaminants in cell cultures. ${ }^{40}$ They were believed to have cytadherence ability but some species (M. genitalium, M. pneumoniae, M. penetrans) have been noted intracellularly too. ${ }^{41}$ During mycoplasma infection, a cell line undergoes either severe or very little cytopathological change, depending upon the type of mycoplasma contamination. The cellular protein, and DNA and RNA synthesis gets altered along with cellular metabolism causing changes in cell membrane composition. The surface antigen and receptor expression change, causing induction or suppression of cytokine expression. The cell growth slows down and cells adherence ability gets compromised. Along with these changes, the cell culture degrades. ${ }^{39}$ Bacterial contamination initially leads to increased turbidity and $\mathrm{pH}$ change indicated by a change in the colour of the medium (Figure 3 ). The cells in the initial stages of contamination continue to grow normally till the change in $\mathrm{pH}$ affects the normal growth of cell, thereby leading to its death within few days after contamination. ${ }^{42}$ The fungal contamination appears unattached to cells or flask. Thin filamentous mycelia and clumps of spores are produced in media (Figure 1). This contamination can be seen with a low power microscope and with naked eye in advanced stages. The advanced mycelial growth stages look like large fuzzy patches. In the early stages of fungal contamination, there is no significant $\mathrm{pH}$ change of the medium and no impact on cell growth. Over a period of time, once the contamination outgrows cell culture, $\mathrm{pH}$ changes and turbidity in the medium is visible affecting cell growth, since fungi compete for nutrients. The changed in $\mathrm{pH}$ makes the environment adverse for culture of desired cell and its survival. ${ }^{43}$

\section{Elimination and prevention of microbial contamina- tion}

The culture contamination may be biological or chemical, visible or invisible, minor, in which several plates or flasks are lost, or major, in which a complete experiment or culture is lost. Contamination, even though it is minor, compromises the quality of the research and adversely affects results, leading to wrong conclusions. While the chemical contaminants (reagents, water, serum, growth supplements, and containers used for storage of the media and media supplements) are non-living substances that cause undesirable effects on growing culture and can be eliminated by sterile culture practices, contaminations by microorganisms cannot be 
dealt with in a similar way. Standard practices to contain the growth of microorganisms in animal cell culture are summarized in Table 3. Ordinarily, in order to prevent common contaminants, always highly purified water, which has leached out metal ions, organic compounds and endotoxin, should be used for all purposes from preparing media to washing and rinsing glassware and preparation and storage of media and media supplements. ${ }^{44}$ Sera should always be tested for sterility before experiment and for experimental reproducibility, and always a single lot of serum should be used ${ }^{45}$ (Esber et al 1973). All media, media supplements and reagents should be tested for sterility before experiment, weighed and used only in required concentration. Always manufacturer's sterilised culture flasks should be used. Utmost care should be taken at the time of opening of these under hood and for further storage in sterile places. Glass and plastic storage vessels must be used for the purpose for which they are designed. ${ }^{46}$ In case of biological contamination, the longer the period that the (biological) contamination goes undetected, the greater the damage to experimental work. A number of tests are to be run in order to indentify biological contamination and its sources, thus eliminating the contaminant and avoiding further incoming contaminations. To detect bacteria and fungi contaminants, sterility tests utilizing several media are run. The mycoplasma contamination and viral contamination require extensive in vitro and in vivo assays. Once the contamination is established, contaminating microorganism spreads via aerosols. Pipetting generates aerosols of potentially infectious droplets flying to survive for days on all contacted surfaces. ${ }^{47}$ Certain human activities that generate contaminated airborne particles and aerosols which are introduced into the cell culture through human error are tricky to handle.

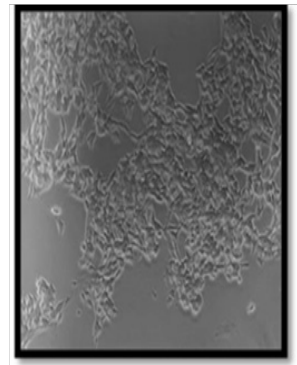

(A)

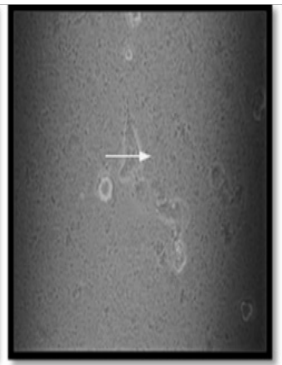

(B)

(C)

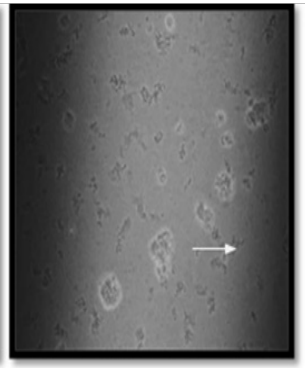

Figure 3 WRL68 cell line showing bacterial contamination. (A) Represents control with clear media and intact cell growth, $(B)$ and $(C)$ indicate culture contaminated with bacteria, resulting in a turbid medium and deformed cell growth (shown by white arrow). Magnification, I0X.

The antibiotic and antimycotic solutions that are commonly used to kill and inhibit the growth of a contaminating microorganism are enlisted in Table 4. It should be kept in mind that one antibiotic is not sufficient for all bacteria since some antibiotics like penicillin are specifically for gram positive bacteria while some like Nisin are exclusively for gram negative bacteria. ${ }^{48}$ Species like mycoplasma have no cell wall; therefore cell wall inhibiting antiobiotics, such as penicillin and cephalosporin etc, are not effective. ${ }^{49}$ Removal of antibiotics should be the first step in order to maintain a good running culture. It is pertinent to mention here that if good culture practices are followed, then culture growth is not dependant on antibiotics. The constant use of antibiotics does not eliminate contamination, but represses it. In such cases, culture coexists with contamination and contamination resurfaces the moment microorganisms become resistant to antibiotics. A contaminated culture which cannot be discarded, should be for at least three passages in presence of antibiotic and then grown with reduced concentrations of antibiotic. The culture

should finally be tested contamination free and cryo-preserved as a sample. It should be revived in an antibiotic free culture medium. Antibiotics that fail tend to make the organism more potential contaminant of other cultures. ${ }^{50}$ After the antibiotic is gone, cultures should be tested for sterility and mycoplasma. All contamination incidences should be documented to avoid future incidences and identify contaminations. The standardised procedures and training protocols should be followed strictly on a timely basis..$^{13,51}$ Improper handling usually leads to mixing and contamination, and therefore utmost care should to taken by avoiding conversations, coughing, sneezing, spilling of medium on surfaces and accidental touching of pipettes to surfaces. ${ }^{52-54}$

Table 3 Standard practices to contain the growth of microorganisms in animal and stem cell culture

\section{Possible \\ source of \\ contamination}

\begin{tabular}{|c|c|}
\hline $\begin{array}{l}\text { Continuous cell } \\
\text { lines }\end{array}$ & $\begin{array}{l}\text { Authenticated stocks of a continuous cell line should } \\
\text { be procured from a recognised repository, such } \\
\text { as the Deutsche Sammlung von Micro organismen } \\
\text { und Zellkulturen GmbH (DSMZ) in Germany, the } \\
\text { American Type Culture Collection (ATCC), the Riken } \\
\text { Gene Bank in Japan, the European Collection of } \\
\text { Animal Cell Cultures (ECACC) in UK, or National } \\
\text { Centre for Cell Science (NCCS) in India, etc }\end{array}$ \\
\hline
\end{tabular}

All possible details regarding culturing a particular cell line (Nomenclature, LOT number, Origin of cell line Culturing cells and media, Passage number, Culturing temperature, $\mathrm{CO}_{2}$ requirement, Sub-culturing frequency, Cryopreservation and storage conditions) should be recorded

Lab personnel etiquettes

Airborne particles and aerosols

\section{Cell culture} medium and supplements like sera, trypsin etc

Glassware, bottles, pipettes etc

\section{Plastic}

disposables, culture flasks

Fluorescent lights and HEPES buffer

Gases
Cleanliness should be maintained.All exposed surfaces must be cleaned thoroughly with $70 \%$ alcohol. Care should be taken to avoid talking, coughing and sneezing during handling

Always use laminar flow hood and clean lab coats. Doors and windows must be sealed or opened least

Sera should be obtaining from authenticated suppliers and same LOT number should be used. The concentration/activity of growth factors must be expressed, Units/ml, as per WHO standard. The culture medium should be always membrane filtered through a $0.22 \mu$ filter and tested for no contamination before culturing cells. PBS and other growth supplements should be either filtered or obtained from authentic sterile sources

Always use autoclaving or dry heat sterilization methods

These are heat/gamma irradiated by suppliers, so care should be taken while opening them under sterile environment

Generation of free radicals should be avoided by exposing culturing cells or medium to minimum light ${ }^{47}$

$\mathrm{CO}_{2}$ incubators should have HEPA filter to prevent contamination through $\mathrm{CO}_{2}$ cylinders 
Table 4 Antibiotic and antimycotic solutions used to inhibit the microbial growth in culture medium

\begin{tabular}{|c|c|c|}
\hline $\begin{array}{l}\text { Antibiotic and } \\
\text { antimycotic } \\
\text { solutions }\end{array}$ & Concentration & $\begin{array}{l}\text { Effective } \\
\text { against }\end{array}$ \\
\hline $\begin{array}{l}\text { Penicillin- } \\
\text { Streptomycin }\end{array}$ & $\begin{array}{l}50-100 I U / m l \\
\text { penicillin and } \\
50-100 \mu g / m l \\
\text { streptomycin }\end{array}$ & $\begin{array}{l}\text { Bacteria and } \\
\text { fungi }\end{array}$ \\
\hline Amphotericin B & $2.5 \mu \mathrm{g} / \mathrm{ml}$ & $\begin{array}{l}\text { Fungi including } \\
\text { yeast }\end{array}$ \\
\hline Gentamicin sulfate & $5-50 \mu \mathrm{g} / \mathrm{ml}$ & $\begin{array}{l}\text { Bacteria, } \\
\text { including } \\
\text { mycoplasma }\end{array}$ \\
\hline Kanamycin sulfate & $100 \mu \mathrm{g} / \mathrm{ml}$ & $\begin{array}{l}\text { Bacteria, } \\
\text { including } \\
\text { mycoplasma }\end{array}$ \\
\hline Neomycin sulfate & $50 \mu \mathrm{g} / \mathrm{ml}$ & Bacteria \\
\hline Polymixin B sulfate & $100 \mathrm{U} / \mathrm{mL}$ & Bacteria \\
\hline Streptomycin sulfate & $50-100 \mu \mathrm{g} / \mathrm{ml}$ & Bacteria \\
\hline Nystatin & $\mathrm{I} 00 \mathrm{U} / \mathrm{ml}$ & $\begin{array}{l}\text { Fungi including } \\
\text { yeast }\end{array}$ \\
\hline
\end{tabular}

\section{Conclusion}

Microbial contamination and spoilage of cell cultures is a common problem in stem cell and animal cell culture laboratories. This mini review provides a brief account of the incidence, sources, effects and methods of detection, elimination and prevention of microbial contamination of cell cultures for smooth.

\section{Acknowledgements}

None.

\section{Conflict of interest}

The author declares no conflict of interest.

\section{References}

1. Routray I, Mahmood A, Ngwa NE, et al. Cell line cross-contamination and accidental co-culture. Journal of Stem Cell Research \& Therapeutics. 2016;1(5):00031

2. Cobo F, Cortés JL, Cabrera C, et al. Microbiological contamination in stem cell cultures. Cell Biol Int. 2007;31(9):991-995.

3. Klein MA, Kadidlo D, McCullough J, et al. Microbial contamination of hematopoietic stem cell products: incidence and clinical sequelae. Biol Blood Marrow Transplant. 2006;12:1142-1149.

4. Honohan A, Olthuis H, Bernards AT, et al. Microbial contamination of cord blood stem cells. Vox Sang. 2002;82(1):32-38.

5. Lodish H, Berk A, Zipursky SL, et al. Molecular Cell Biology. 4th ed USA: WH Freeman; 2000.

6. Zhao Y, Wieman HL, Jacobs SR, et al. Mechanisms and methods in glucose metabolism and cell death. Methods Enzymol. 2009;442:439-457.
7. Frigault MM, Lacoste J, Swift JL, et al. Live-cell microscopy - tips and tools. J Cell Science. 2009;122(Pt 6):753-767.

8. Casey JR. Why bicarbonate? Biochem Cell Biology. 2006;84(6):930939

9. Bates MK, Wernerspach D. Cell Culture Contamination. 2011.

10. McGarrity GJ, Kotani H. Mycoplasmas and tissue culture cells. In Maniloff J, McElhaney RN, editors. Mycoplasmas - molecular biology and pathogenesis. USA: American Society for Microbiology; 1992. p. 445-454.

11. Nikfarjam L, Farzaneh P. Prevention and detection of mycoplasma contamination in cell culture. Cell Journal (Yakhteh). 2012;13(4):203-212.

12. Barile MF. Mycoplasma contamination of cell cultures: Mycoplasmae virus-cell culture interactions. In: Fogh J, editor. Contamination of tissue culture. England: Academic Press Inc; 1973. 132e56 p.

13. Mirjalili A, Parmoor E, Moradi Bidhendi S, et al. Microbial contamination of cell cultures: a 2 years study. Biologicals. 2005;33(2):81-85.

14. Hopert A, Uphoff CC, Wirth M, et al. Specifity and sensitivity of polymerase chain reaction (PCR) in comparison with other methods for the detection of mycoplasma contamination in cell lines. Journal of immunological methods. 1993;164(1):91-100.

15. Ascioglu S, Rex JH, de Pauw B, et al. Defining opportunistic invasive fungal infections in immunocompromised patients with cancer and hematopoietic stem cell transplants: an international consensus. Clinical Infectious Diseases. 2002;34(1):7-14.

16. Merten OW. Virus contaminations of cell cultures-a biotechnologica view. Cytotechnology. 2002;39(2):91-116.

17. Strickler HD, Rosenberg PS, Devesa SS, $t$ al. Contamination of poliovirus vaccines with simian virus 40 (1955-1963) and subsequent cancer rates. JAMA. 1998;279(4):292-295.

18. Moore WA. Experience in cell line testing. Animal Cell Technology: Basic \& Applied Aspects. Netherlands: Springer; 1992. p. 9-14.

19. Mayor HD, Melnick JL. Small deoxyribonucleic acid containing viruses. Nature. 1966;210:331-332.

20. Nakai N, Kawaguchi C, Nawa K, et al. Detection and elimination of contaminating microorganisms in transplantable tumors and cell lines. Experimental Animals. 2000;49:309-313.

21. Lusso P, Lori F, Gallo RC. CD4-independent infection by human immunodeficiency virus type 1 after phenotypic mixing with human T-cell leukemia viruses. J Virol. 1990;64(12):6341-6344.

22. Mahy BW, Dykewicz C, Fisher-Hoch S, et al. Virus zoonosis and their potential for contamination of cell culture. Dev Biol Stand. 1991;75:183-189.

23. Merten OW. Safety issues of animal products used in serum-free media. Dev Biol Stand. 1998;99:167-180.

24. Barile MF, Schimke RT. A rapid chemical method for detecting PPLO contamination of tissue cell cultures. Experimental Biology and Medicine. 1963;114(3):676-679.

25. Masters J. Short tandem repeat profiling provides an internationa reference standard for human cell lines. Proc Natl Acad Sci USA. 2001;98(14):8012-8017.

26. ANSI/ATCC ASN-0002-2011 Authentication of human cell lines Standardization of STR profiling.

27. Capes-Davis A, Theodosopoulos G, Atkin I, et al. Check your cultures! A list of cross-contaminated or misidentified cell lines. Int J Cancer. 2010;127(1):1-8. 
28. Almeida JL, Hill CR, Cole KD. Mouse cell line authentication. Cytotechnology. 2014;66(1):133-147.

29. Birney E, Andrews TD, Bevan P, et al. An overview of Ensembl. Genome Research. 2004;14(5):925-928.

30. Freshney RI. Culture of animal cells: a manual of basic technique and specialized applications. 6th ed. USA: Wiley-Blackwell; 2010.

31. MacLeod RA, Drexler HG. Public repositories: users reluctant to give materials. Nature. 2006;439(7079):912.

32. O'Donoghue LE, Rivest JP, Duval DL. Polymerase chain reaction-based species verification and microsatellite analysis for canine cell line validation. $J$ Vet Diagn Invest. 2011;23(4):780-785.

33. Losi CG, Ferrari S, Sossi E, et al. An alternative method to isoenzyme profile for cell line identification and interspecies cross-contaminations: cytochrome b PCR-RLFP analysis. In Vitro Cell Dev Biol Anim. 2008;44(8-9):321-329.

34. Drexler HG, Gignac SM, Hu ZB, et al. Treatment of mycoplasma contamination in a large panel of cell cultures. In Vitro Cell Dev Biol Anim. 1994;30A(5):344-347.

35. Pachucki CT, Khurshid MA, Nawrocki J. Utility of reverse transcriptase PCR for rapid diagnosis of influenza A virus infection and detection of amantadine-resistant influenza A virus isolates. Journal of clinical microbiology. 2004;42(6):2796-2768.

36. Böni J, Stalder J, Reigel F, et al. Detection of reverse transcriptase activity in live attenuated virus vaccines. Clin Diagn Virol. 1996;5(1):43-53.

37. Fischer SA, Graham MB, Kuehnert MJ, et al. Transmission of lymphocytic choriomeningitis virus by organ transplantation. $N$ Engl J Med. 2006;354:2235-2249.

38. Ellis AE, Mead DG, Allison AB, et al. Comparison of Immunohistochemistry and Virus Isolation for Diagnosis of West Nile Virus. J Clin Microbiol. 2005;43(6):2904-2908.

39. Esber HJ, Payne IJ, Bogden A. Variability of hormone concentrations and ratios in commercial sera used for tissue culture. Journal of the National Cancer Institute. 1973;50(2):559-562.

40. Drexler HG, Uphoff CC. Mycoplasma contamination of cell cultures: Incidence, sources, effects, detection, elimination, prevention. Cytotechnology. 2002;39(2):75-90.
41. Pinheiro de Oliveira TF, Fonseca AA, Camargos MF, et al. Detection of contaminants in cell cultures, sera and trypsin. Biologicals. 2013;41(6):407-414.

42. Lo SC, Hayes MM, Tully JG, et al. Mycoplasma penetrans sp. Nov., from the urogenital tract of patients with AIDS. Int J Syst Bacteriol. 1992;42(3):357-364.

43. Brînzeu DGT, Feier V, Herbeck R, et al. Microbial and fungal contamination of keratinocyte and fibroblast cell cultures. Journal of Experimental Medical \& Surgical Research. 2008:123-128.

44. Doyle A, Bryan GJ. Cell and tissue culture: laboratory procedure in biotechnology. USA: John Willey \& Sons; 1998.

45. Phelan MC. Techniques for mammalian cell tissue culture. Curr Protoc Cell Biol. 2006:A-3F.

46. Kenny GE. Contamination of mammalian cells in culture by mycoplasmata. In: Fogh J, editor. Contamination of tissue culture. UK: Academic Press Inc; 1973. p. 108-126.

47. Langdon SP. Cancer cell culture: methods and protocols. Methods in Molecular Medicine. 2004;88:309-317.

48. McGarrity GJ, Wanaman V, Sarama J. Methods of prevention, control and elimination. Mycoplasma Infection of Cell Cultures. 2012;3:213241.

49. Stevens KA, Sheldon BW, Klapes NA, et al. Nisin treatment for inactivation of Salmonella species and other gram-negative bacteria. Appl Environ Microbiol. 1991;57(12):3613-3615.

50. Lincoln CK, Gabridge MG. Cell culture contamination: sources, consequences, prevention, and elimination. Methods Cell Biol. 1998;57:4965 .

51. Geraghty RJ, Capes-Davis A, Davis JM, et al. Guidelines for the use of cell lines in biomedical research. Br J Cancer. 2014;111(6):1021-1026.

52. Ryan J. Understanding and managing cell culture contamination. UK: Technical Bulletin; 2008. p. 1-24.

53. Rottem S, Kosower NS, Kornspan JD. Contamination of Tissue Cultures by Mycoplasmas. Biomedical Tissue Culture. 2012.

54. Stacey GN. Cell culture contamination. Methods Mol Biol. 2011;731:7991. 